\title{
Mechanism of Supply Chain Coordination based on Dynamic Capability Framework-the mediating Role of Manufacturing Capabilities
}

\author{
Tiantian Gao, Yezhuang Tian \\ School of Management, Harbin Institute of Technology (China)
}

gaotiantianme@163.com,tianyezbuang@,bit.edu.cn

Received: September 2014

Accepted: October 2014

\section{Abstract:}

Purpose: A critical issue has been absent from the conversation on supply chain coordination: how supply chain coordination influence the enterprise performance. This research proposes a new vision to research the performance mechanism of supply chain coordination capability as a dynamic capability. Manufacturing capabilities are existed as mediating role.

Design/methodology/approach: Data from International Manufacturing Strategy Survey in 2009 is used to verify the mediating model by hierarchical regression analysis.

Findings: The results show that supply chain coordination impacts the enterprise performance positively and indirect impacts the enterprise performance through quality, cost, and flexibility.

Research implications: This study presents an overview of the impact of supply chain coordination and manufacturing capabilities on enterprise performance, giving grasp for further research of the relationships that exist between them.

Originality/value: This finding integrates insights from previous research in dynamic capability framework and supply chain management into a generalization and extension of the performance mechanism in manufacturing enterprises.

Keywords: supply chain coordination, dynamic capability, manufacturing capability, enterprise performance 


\section{Introduction}

Supply chain has become one of the most popular words in business and academe. With the speeding up of economic globalization, enterprises face the competition from domestic to regional, then to international. On the one hand, technological innovation is quickened enterprise external competitive environment presenting a sharp change of dynamic. Knowledge and technology, on the other hand, have the decisive influence to the business performance and competitive advantage which becoming more and more outstanding. Of course, opportunity is along with the heated competition. It has become the urgent task for firms to cooperate with partners in the supply chain through the global supply chain management.

Supply chain coordination is one of the important areas of supply chain management research (Ballou \& Gilbert, 2000). Manufacturing enterprises need to obtain competitive advantage through the supply chain coordination. Existing literature on the relationship between the supply chain coordination and performance are studied, but the conclusions are inconsistent (Wong, Sakun \& Wong, 2011). Kim (2009) thinks the supply chain coordination can promote the cost performance of manufacturing enterprises. Wang and Meng (2004) suggests that supply chain coordination can effectively improve manufacturing enterprises in finance, product quality, delivery, customer satisfaction and overall enterprise performance. But Shawnee (2003) consider that there is no direct relation between supply chain coordination and financial performance. At the same time, some scholars have found that supply chain coordination has not simply directly effect on enterprise performance, but more complexes intermediate links (Vickery, Jayaram, Droge \& Calantone, 2003).

Because of the supply chain coordination performance mechanism is still in controversy, some scholars tried to reveal the black box of supply chain coordination mechanism performance with the key elements of internal non-market factors as the breakthrough point. Dynamic capabilities framework relying on resource-based view proposes a new interpretation for supply chain coordination mechanism performance (Heimerik, 2004).

The primary premise of the dynamic capability framework is that a firm has operational capabilities and resources that are directly involved in enterprise performance by converting inputs into outputs and dynamic capabilities that influence enterprise performance indirectly by updating, integrating and reconfiguring a firm's existing operational capabilities and resources (Teece, Pisano \& Shuen, 1997). Supply chain coordination, as one of the important method to integrate and coordinate enterprise external resources, it can be seen as a kind of dynamic capability. As the research objects of this article are manufacturing enterprises, manufacturing capability is the most basic part of the original capability and the core operational capability in manufacturing enterprise. Based on the above reasons, this research will regard supply chain coordination as the dynamic capability, while manufacturing capability as the operational 
capability in dynamic capability framework. Supply chain coordination performance mechanism is researched through the dynamic capabilities framework.

Although the dynamic capability framework argues that dynamic capabilities influence enterprise performance by renewing operational capabilities, it is unclear from prior studies whether supply chain coordination actually influence enterprise performance through manufacturing capabilities. It is also unclear whether supply chain coordination influences enterprise performance through the renewal of a single manufacturing capability or several of them. This research provide a way to investigate empirically whether a given dynamic capability influences enterprise performance by updating (renewing) a single manufacturing capability or a number of them.

\section{Literature review and hypothesis}

\subsection{Dynamic capability framework}

Based on resource-based view, Teece et al. (1997) first proposed the dynamic capability framework. In this model, dynamic capabilities emphasize the transforming of environmental characteristics and how the firms manage to adapt, integrate, and reconfigure the internal and external organizational resources to compete with the dynamic environmental conditions (Teece, 2007). Eisenhardt and Martin (2000) expand on Teece and Pisano's earlier view that dynamic capabilities are not vague but rather exhibit commonalities with greater equifinality, homogeneity, and substitutability across firms. Rather than focusing on how dynamic capabilities reconfigure operational capabilities, the second stream of literature investigates how a firm uses its dynamic capabilities to reconfigure tangible and intangible resources (Helfat \& Peteraf, 2003). Wang and Ahmed (2007) draw from the existing empirical findings and identify three main elements of dynamic capabilities: adaptive capability, absorptive capability, and innovative capability. Dynamic capabilities are organizational routines, which must be obtained by learning with highly stylized, repeatable or quasi- repeatable.

Although many scholars make interpretation of dynamic capabilities, the most far-reaching dynamic capability framework is still proposed by Teece (Figure 1). This article is studied under this framework. 


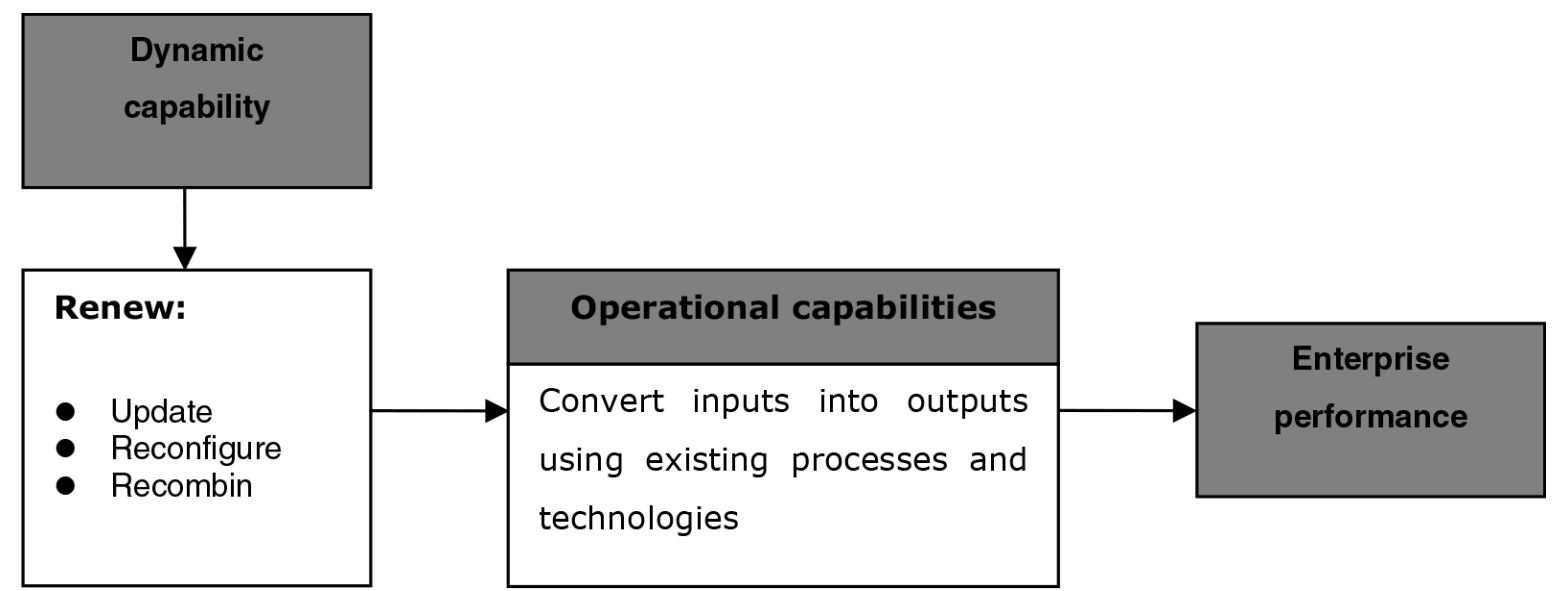

Figure 1. Dynamic capability framework (Teece et al., 1997)

\subsection{Supply chain coordination}

According to the dynamic capability framework, a firm's supply chain coordination is considered a dynamic capability because supply chain coordination can be used to renew a firm's operational capabilities (Teece, 2007). Supply chain coordination is refers to the enterprise to maintain the relationship between customers and suppliers and force to adapt the demand of the competitive environment. In terms of enterprise's external environment, these relationships constitute the main inducement of the change in competition environment (Koka \& Prescott, 2008). As a result, the enterprise must be dynamically adjusting these external relations.

At present, the supply chain coordination has a variety of definitions. Simatupang, Wright and Sridharan (2002) points out that supply chain coordination is to joint (combination, coordination, adjustment, alliance) members of the supply chain to achieve supply chain goal. Romano (2003) defines coordination is decision making, communication and interaction between supply chain partners, which can help to plan, control and adjust the materials, spare parts, service, information, funds, members and methods involved in supply chain, and support the key business process in supply chain network. Gan, Sethi and Yan (2004) proposes a risk averse agent definition of supply chain coordination. This definition summarizes the coordination standard in risk neutral condition. They point out that coordinate a supply chain need to select the appropriate external joint action and internal income distribution plan, find a Pareto optimal solutions can be accepted by each agent. The supply chain will achieve coordination if meet the following three conditions: (1) the payment gotten by sales and suppliers is not less than their reservation utility; (2) satisfy the downside risk constraint of sellers; (3) get the maximization of expected profit. Stank (1999) focuses supply chain coordination on manufacturing enterprises and other enterprises within the supply chain, including supplier and customer. Arshinder, Kanda and Deshmukh (2008) proposes that supply chain coordination includes coordination of logistics and information flow of elements. 
Based on the above literature, this paper argues that supply chain coordination of manufacturing enterprise is a different method or tool adopted by manufacturing enterprises, coordinating for suppliers and customers in the process of logistics and information flow.

\subsection{Manufacturing capability}

Manufacturing capability is the core operational capability in manufacturing enterprises. Since the modern management science applied to manufacturing enterprises, manufacturing capability is not simply referring to the enterprise's production and the production varieties, etc. It has become a measure in the process of production with extensive significance. Taylor (1911) proposes that a firm should develop two tiers of interdependent manufacturing capabilities: (1) the capacity to plan the most efficient work method for a given task, and (2) the capacity of line workers to execute a given activity as planned. Skinner (1969) consider that manufacturing capability is the most important element to construct the enterprise competitive advantage. Manufacturing can provide organizations with certain competitive power. These capabilities can be used as a competitive weapon, achieving manufacturing performance in cost, quality and time dimensions. Roth and Van Der Velde (1991) argue that manufacturing capability has achieved the strategic capability in the process of manufacturing. It is the strategic transformation of enterprise.

Literature in the operations management field has currently classified manufacturing capabilities into five types: quality, cost, delivery, flexibility, innovation (Ward, Duray, Leozzg \& Sum, 1995). Quality refers to the ability to produce a high quality and high performance product, which is excellent, valuable, and conformable, and then meets or exceeds customer expectations (Reeves \& Bednor, 1994). Cost refers to the ability to produce at low cost by reducing inventory, increasing equipment and capacity utilization (Corbett \& Van Wassehnove, 1993). Delivery refers to the ability to delivery reliability and fast according to the delivery time. Flexibility refers to the ability to meet customer demand according to enterprise's production and management resources. Innovation refers to the ability to develop new products or use new technology in manufacturing process (Burgess, Gules, Gupta \& Tekin, 1998).

\subsection{Supply chain coordination, manufacturing capability and enterprise performance}

Teece et al. (1997) propose dynamic capability to explain why some organizations are more successful than others in establishing competitive advantages in dynamic markets. As a dynamic capability, coordinating with customers and suppliers can achieve performance improvement through continuous absorption and transformation of external information and resources. Petersen, Handfield and Ragatz (2005) establish a theoretical model reveals the 
high quality of the information exchange between supply chain members will improve the joint planning and the decision making process, so as to improve the performance of the enterprise. Research of Clark and Hammond (1997) has shown that channel performance, mutual dependence and coordination have significant correlation to cross-organizational cooperation enterprises. Morris (2005) explores the relationship between relationship trading and the performance in supply chain cooperation. The results show that there is significant correlation between coordination, uncertainty and supply chain performance. Eng (2005) considers that functional integration in supply chain will improve the supply chain performance. Brian and Chris (2005) point that the management of supply chain partnership positively affect the manufacturing performance. Li (2006) uses strategic supplier relationship management, customer relationship, information sharing level, information sharing quality and postponement to describe the supply chain coordination, and researches the positive relationship between coordination behavior and competitive advantage. The unique management model of suppliers, distributors and terminal customer in Dell is proved that coordination capability can create extraordinary performance and competitive advantage.

\section{H1: Supply chain coordination will have a positive relationship on enterprise} performance.

In addition, some scholars have found that supply chain coordination has not simply directly effect on enterprise performance, but more complex intermediate links. Danneels (2011) finds that the relationship between the supply chain coordination and market performance is significant, while the significance is small. The results show that there are other intermediary variables between supply chain coordination and performance. Some qualitative researches consider that the manufacturing capability may be the intermediate link between supply chain coordination and performance. This conclusion is supported by dynamic capability framework: supply chain coordination creates and forms the potential resource and related capabilities, which further effect on performance (Zott, 2003).

The core of supply chain coordination is the fast resource recognition and effective resource flow between stakeholders in supply chain. It is easier for suppliers and customers to understand the requirement of enterprise by coordinating the resource. The information about the products, processes, plans, and ability to the interactive exchange process help manufacturing enterprises to develop their production plan and improve the quality. This procedure meets customers' requirements and expectations and eventually influences a firm's overall performance.

H2a: Supply chain coordination capability will have a positive relationship on quality capability.

H2b: Quality capability mediates the relationship between supply chain coordination capability and enterprise performance. 
Flow of information resources provides the path to solve the problem across the enterprises, creating a way for stakeholders to understand each other. It is beneficial to help to manage the behavior of the entire supply chain partners and reduce the waste (Swink, Narasimhan \& Wang, 2007). Supply and demand information resources can be feedback to the production, R\&D, design department by supply chain coordination. It modifies the existing process and creates a new process, reducing the cost of inconformity. Lower prices and higher operating efficiency provide customers with low cost products. When other firms lose profit in competition, the enterprise can still make a profit.

H3a: Supply chain coordination capability will have a positive relationship on cost capability.

H3b: Cost capability mediates the relationship between supply chain coordination capability and enterprise performance.

Supply chain coordination can also help enterprises to develop their production plan and produce products in time for the information interaction exchange in product, process and plan. Identification of external resources effectively can help to resolve the conflict between the targets and reduce inventory. It will lead to better delivery capability based on time (Rosenzweig, Roth \& Dean, 2003). High elastic delivery capability can improve the reliability and speed to implement differentiated competition, conducive to enterprise to predict the market and response to customer demand. It eventually influences a firm's overall performance.

H4a: Supply chain coordination capability will have a positive relationship on delivery capability.

H4b: Delivery capability mediates the relationship between supply chain coordination capability and enterprise performance.

A firm that produces a wide variety of products must be able to switch from performing a set of interdependent activities required to produce a given product to a different set of activities essential to produce an entirely different product. The various activities required to produce a variety of products are performed by different departments and individuals, thereby requiring a firm to coordinate those interdependent activities effectively to gain a competitive advantage. Supply chain coordination make enterprises a better understanding of the potential demand of customers (Slater \& Narver, 1994), promoting the flexibility by allowing participation for partners in supply chain. To produce a variety of products, a firm must be able to effectively coordinate the completion of all the tasks and activities required to produce those products.

H5a: Supply chain coordination capability will have a positive relationship on flexibility capability. 
H5b: Flexibility capability mediates the relationship between supply chain coordination capability and enterprise performance.

The stronger the coordination of supply chain is, the enterprise is more able to quickly and accurately identify rich innovation opportunities and to enhance enterprise's innovation consciousness and innovation power. Under the condition of high technology uncertainty, manufacturing companies are more likely to have high levels of external resources integration. As external resources, supply chain coordination can promote the new product development performance so as to promote the innovation of the manufacturing enterprise performance (Ragatz, Handfield \& Petersen, 2002). Petersen et al. also show that the effective identification to relationship between supplier and customer promote the effectiveness of the new product development, so as to get the manufacturing enterprise's financial performance and innovation performance (Petersen et al., 2005).

H6a: Supply chain coordination capability will have a positive relationship on innovation capability.

H6b: Innovation capability mediates the relationship between supply chain coordination capability and enterprise performance.

Through the analysis of the relationship between supply chain coordination, manufacturing capability and enterprise performance, the schematic diagram of supply chain coordination causal mechanism in this paper is shown in Figure 2:

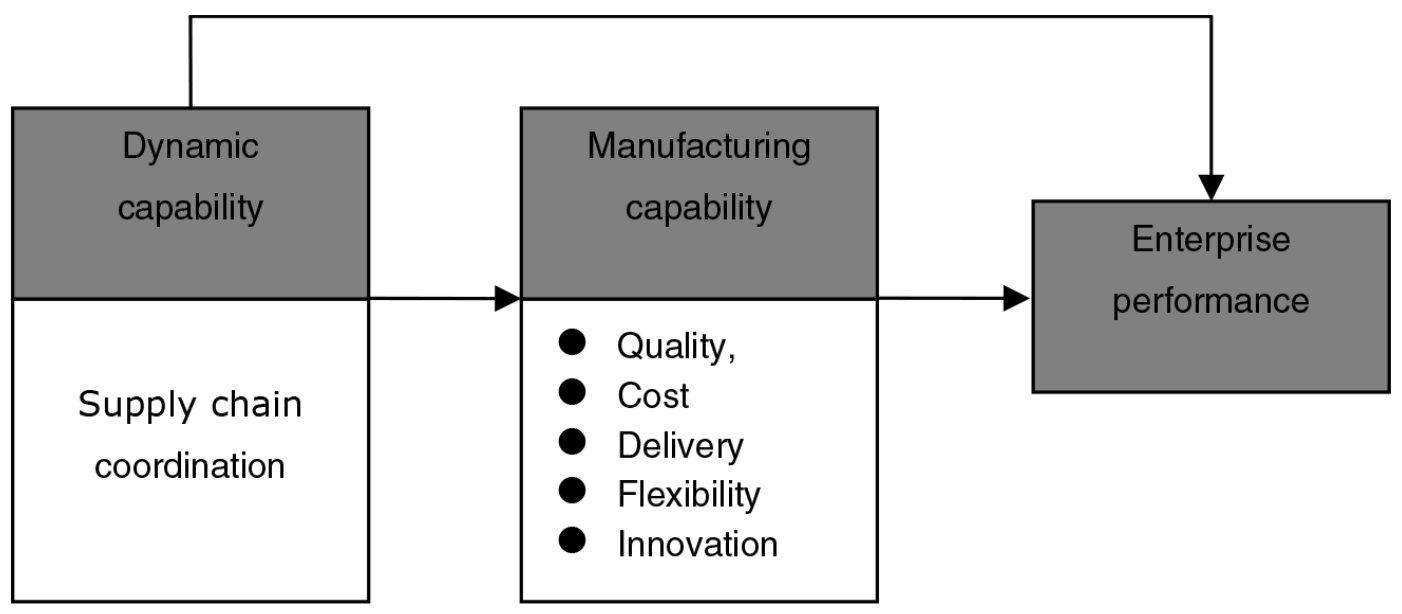

Figure 2. Schematic diagram of supply chain coordination causal mechanism 


\section{Data analysis and empirical results}

\subsection{Data source}

The paper data comes from the fifth edition of the International Manufacturing Strategy Survey in 2009 (International Manufacturing Strategy Survey, IMSS-V). The project which is launched by professor Voss and professor Lindberg in London business school of Sweden's university of moss, It is designed for the research of manufacturing enterprise strategy, practice and performance in the world. This investigation is mainly in the form of questionnaire mainly using Likert five-point scale, including 719 enterprises in 20 countries. All enterprises are classified according to the International Standard industrial (International Standard Industry Code, ISIC) 28-35, belonged to industrial and business operation entity. There are 510 samples of eight industries after removing the missing values. The samples of industries and geographical distribution are shown in Tables 1 and 2 .

\begin{tabular}{|c|l|c|}
\hline No. & Industries & Percent (\%) \\
\hline 28 & Metal manufacturing, except the machinery and equipment & 38.6 \\
\hline 29 & Machinery and equipment & 20.9 \\
\hline 30 & Office, accounting and computer & 2.29 \\
\hline 31 & Electrical equipment and instrument & 13.3 \\
\hline 32 & Radio, television and communication equipment & 5.78 \\
\hline 33 & Medical equipment, precision instruments & 4.45 \\
\hline 34 & Motor vehicle, trailer, semi-trailer & 9.59 \\
\hline 35 & Other transportation equipment & 5.87 \\
\hline
\end{tabular}

Table 1. The samples of industries distribution

\begin{tabular}{|c|c|c|c|c|c|}
\hline Region & Country & Percent $(\%)$ & Region & Country & Percent $(\%)$ \\
\hline \multirow{4}{*}{ Asia } & Chinese Mainland & 9.88 & \multirow{9}{*}{ Europe } & Germany & 4.54 \\
\hline & Chinese Taiwan & 5.73 & & Hungary & 8.70 \\
\hline & Japan & 3.16 & & Ireland & 0.79 \\
\hline & Korea & 7.70 & & Italy & 4.83 \\
\hline \multirow{3}{*}{ North America } & America & 10.47 & & Netherlands & 6.13 \\
\hline & Canada & 3.16 & & Portugal & 1.58 \\
\hline & Mexico & 3.36 & & Spain & 4.94 \\
\hline \multirow{3}{*}{ Europe } & Belgium & 5.93 & & Switzerland & 4.74 \\
\hline & Denmark & 2.17 & & England & 3.36 \\
\hline & Estonia & 3.16 & South America & Brazil & 4.74 \\
\hline
\end{tabular}

Table 2. The samples of geographical distribution 


\subsection{Variables measurement}

Enterprise performance is measured by return on sales (ROS) and return on investment (ROI). Supply chain coordination capability measures the extent to which a firm coordinates with its key and strategic customers, suppliers for their plan and resources. Quality capability is measured by what extent a firm produces reliable and conformable products. Cost capability is constructed by the extent to which a firm can produce products at low costs. Delivery capability is constructed by the extent to which a firm delivery reliable and fast. Flexibility capability is constructed by the extent to which a firm can switch from producing one product line to another and the extent to which it can change the rate of production. Innovation capability is constructed by the extent to which a firm can produce new products with quantity and speed. There are special items in allusion to all the variables in IMSS-V questionnaire. Indicators of variables are shown in Table 3.

\begin{tabular}{|c|c|}
\hline Variables & Indicators \\
\hline Enterprise performance & $\begin{array}{ll}\text { 1. } & \text { Return on sales } \\
\text { 2. } & \text { Return on investment }\end{array}$ \\
\hline Supply chain coordination & $\begin{array}{l}\text { 3. Share the information of inventory levels } \\
\text { 4. Share the production plan and demand forecast information } \\
\text { 5. Collaborative planning, forecasting and supplement } \\
\text { 6. Share factories or other facilities with suppliers or customers } \\
\text { 7. Order tracking } \\
\text { 8. Reach an agreement with delivery frequency } \\
\text { 9. Vendor managed inventory (VMI) and consignment inventory } \\
\text { 10. Collaborative planning, forecasting and supplement (CPFR) } \\
\text { 11. Just-in-time (JIT) }\end{array}$ \\
\hline Quality capability & $\begin{array}{l}\text { 12. Consistency of product } \\
\text { 13. Quality and reliability }\end{array}$ \\
\hline Cost capability & $\begin{array}{l}\text { 14. Unit production costs } \\
\text { 15. Productivity } \\
\text { 16. Inventory carry rate } \\
\text { 17. Capacity utilization rate }\end{array}$ \\
\hline Delivery capability & $\begin{array}{l}\text { 18. Delivery reliability } \\
\text { 19. Delivery speed }\end{array}$ \\
\hline Flexibility capability & $\begin{array}{l}\text { 20. Product customization } \\
\text { 21. Production flexibility } \\
\text { 22. Variety flexibility }\end{array}$ \\
\hline Innovation capability & $\begin{array}{l}\text { 23. Product innovation } \\
\text { 24. Time to Market }\end{array}$ \\
\hline
\end{tabular}

Table 3. Indicators of variables

\subsection{Reliability and validity}

This paper uses SPSS 17.0 to test reliability. Cronbach's Alpha coefficients of all variables are greater than 0.6, showing good reliability. Confirmatory factor analysis show fitting index as followed: chi square $/ \mathrm{df}=1.91, \mathrm{RMSEA}=0.071, \mathrm{CFI}=0.92, \mathrm{GFI}=0.81, \mathrm{AGFI}=0.903$. Model fitting results are good, and at the same time the factor loading coefficient of each variable shows good convergent validity. The square root of average extraction variance (AVE) of each 
variable is greater than the correlation coefficient of this variable with other variables, which has better discriminant validity. Reliability, validity of test results and the correlation matrix are shown in Table 4.

\begin{tabular}{|l|c|c|c|c|c|c|c|c|c|c|}
\hline Variables & Cronbach's $\alpha$ & Mean & s.d. & $\mathbf{1}$ & $\mathbf{2}$ & $\mathbf{3}$ & $\mathbf{4}$ & $\mathbf{5}$ & $\mathbf{6}$ & $\mathbf{7}$ \\
\hline $\begin{array}{l}\text { Supply chain } \\
\text { coordination }\end{array}$ & .728 & 3.21 & .901 & .782 & & & & & \\
\hline Quality capability & .842 & 3.87 & .913 & $.215^{* *}$ & .776 & & & & \\
\hline Cost capability & .877 & 3.35 & .921 & $.198^{* *}$ & $-.282^{* *}$ & .836 & & & & \\
\hline Flexibility capability & .820 & 3.82 & .886 & $.188^{* *}$ & $.113^{*}$ & $.282^{* *}$ & .817 & & \\
\hline Delivery capability & .808 & 3.41 & .878 & $.277^{* *}$ & $.246^{* *}$ & $.217^{* *}$ & $.453^{* *}$ & .798 & & \\
\hline Innovation capability & .813 & 3.08 & .779 & $.205^{* *}$ & $.351^{* *}$ & -.038 & $.309^{* *}$ & $.228^{* *}$ & .812 & \\
\hline $\begin{array}{l}\text { Enterprise } \\
\text { performance }\end{array}$ & .890 & 3.26 & .783 & $.201^{* *}$ & $.219 * *$ & $.228^{* *}$ & $.256^{* *}$ & $.224^{* *}$ & $.312^{* *}$ & 817 \\
\hline
\end{tabular}

$\mathrm{N}=510, * * \mathrm{p}<0.001, * \mathrm{p}<0.01$, numbers on the diagonal show square roots of AVE.

Table 4. Reliability, validity and correlation matrix

\subsection{Empirical results}

This paper takes manufacturing capabilities as mediating variables and examines the relationships between supply chain coordination in manufacturing enterprise and performance. Results are shown in Tables 5-9.

In model 2 of Tables 5-9, supply chain coordination has a significantly positive relationship on enterprise performance $(P<0.001)$, providing strong evidence for the hypothesis 1 . Enterprise performance will be promoted when supply chain coordination applying more. In model 1 of Tables $5-9$, supply chain coordination has a significantly positive relationship on $(P<0.001)$ quality capability, cost capability, delivery capability, flexibility capability and innovation capability, providing strong evidence for the hypothesis $2 a, 3 a, 4 a, 5 a, 6 a$. In model 3 of Tables $5,6,8$, the relationship of supply chain coordination and enterprise performance is not significant when entering the manufacturing capabilities. This result shows the completely mediating role of quality capability, cost capability and flexibility capability. The hypothesis $2 b$, $3 b, 5 b$ are verified. In model 3 of Tables 7, 9, the relationship of supply chain coordination and enterprise performance is still significant when entering the manufacturing capabilities. This result shows that the delivery and innovation are not the mediating variables. The hypothesis $4 \mathrm{~b}$ and $6 \mathrm{~b}$ are not verified. Supply chain coordination influences enterprise performance by only renewing quality, cost, and flexibility. 


\begin{tabular}{|l|c|c|c|}
\hline Variables & $\begin{array}{c}\text { Model 1 } \\
\text { Quality capability }\end{array}$ & $\begin{array}{c}\text { Model 2 } \\
\text { Enterprise performance }\end{array}$ & $\begin{array}{c}\text { Model 3 } \\
\text { Enterprise performance }\end{array}$ \\
\hline Supply Chain Coordination & $.211^{* *}$ & $.192 * *$ & .093 \\
\hline Quality capability & & $2.16 * *$ & $2.84 * *$ \\
\hline $\mathrm{F}$ & $2.87 * *$ & .079 & .092 \\
\hline Adjusted $\mathrm{R}^{2}$ & .193 & $.173 * *$ & $.023 *$ \\
\hline$\Delta \mathrm{R}^{2}$ & $.196 * *$ & \\
\hline
\end{tabular}

$\mathrm{N}=510, * * \mathrm{p}<0.001, * \mathrm{p}<0.01$, standardized coefficients are reported.

Table 5. Mediating test of Quality Capability between Supply Chain Coordination and Enterprise performance

\begin{tabular}{|c|c|c|c|}
\hline Variables & $\begin{array}{c}\text { Model } 1 \\
\text { Cost capability }\end{array}$ & $\begin{array}{c}\text { Model } 2 \\
\text { Enterprise performance }\end{array}$ & $\begin{array}{l}\text { Model } 3 \\
\text { Enterprise performance }\end{array}$ \\
\hline Supply Chain Coordination & $.198 * *$ & $.201 * *$ & .078 \\
\hline Cost capability & & & $.261 * *$ \\
\hline $\mathrm{F}$ & $2.44 * *$ & $2.28 * *$ & $2.67 * *$ \\
\hline Adjusted $\mathrm{R}^{2}$ & .186 & .088 & .072 \\
\hline$\Delta \mathrm{R}^{2}$ & $.191 * *$ & $.165 * *$ & $.013^{*}$ \\
\hline
\end{tabular}

$\mathrm{N}=510, * * \mathrm{p}<0.001, * \mathrm{p}<0.01$, standardized coefficients are reported.

Table 6. Mediating test of cost capability between Supply Chain Coordination and Enterprise performance

\begin{tabular}{|l|c|c|c|}
\hline Variables & $\begin{array}{c}\text { Model 1 } \\
\text { Delivery capability }\end{array}$ & $\begin{array}{c}\text { Model 2 } \\
\text { Enterprise performance }\end{array}$ & $\begin{array}{c}\text { Model 3 } \\
\text { Enterprise performance }\end{array}$ \\
\hline Supply Chain Coordination & $.181^{* *}$ & $.178^{* *}$ & $.175^{* *}$ \\
\hline Delivery capability & & & $.223^{* *}$ \\
\hline $\mathrm{F}$ & $1.63^{* *}$ & $1.89 * *$ & $2.03^{* *}$ \\
\hline Adjusted $\mathrm{R}^{2}$ & .137 & .072 & .044 \\
\hline$\Delta \mathrm{R}^{2}$ & $.139 * *$ & $.164 * *$ & $.015^{*}$ \\
\hline
\end{tabular}

$\mathrm{N}=510, * * \mathrm{p}<0.001, * \mathrm{p}<0.01$, standardized coefficients are reported.

Table 7. Mediation test of Delivery capability between Supply Chain Coordination and Enterprise performance

\begin{tabular}{|l|c|c|c|}
\hline Variables & $\begin{array}{c}\text { Model 1 } \\
\text { Flexibility capability }\end{array}$ & $\begin{array}{c}\text { Model 2 } \\
\text { Enterprise performance }\end{array}$ & $\begin{array}{c}\text { Model 3 } \\
\text { Enterprise performance }\end{array}$ \\
\hline Supply Chain Coordination & $.179 * *$ & $.176 * *$ & .081 \\
\hline Flexibility capability & & & $.239 * *$ \\
\hline F & $1.76 * *$ & $2.01 * *$ & $2.09 * *$ \\
\hline Adjusted $\mathrm{R}^{2}$ & .142 & .076 & .063 \\
\hline$\Delta \mathrm{R}^{2}$ & $.136 * *$ & $.157 * *$ & $.012 *$ \\
\hline
\end{tabular}

$\mathrm{N}=510, * * \mathrm{p}<0.001, * \mathrm{p}<0.01$, standardized coefficients are reported.

Table 8. Mediation test of Flexibility capability between Supply Chain Coordination capability and Enterprise performance 


\begin{tabular}{|l|c|c|c|}
\hline Variables & $\begin{array}{c}\text { Model 1 } \\
\text { Innovation capability }\end{array}$ & $\begin{array}{c}\text { Model 2 } \\
\text { Enterprise performance }\end{array}$ & $.183^{* *}$ \\
\hline Supply Chain Coordination & $.174 * *$ & $1.90 * *$ & $.226 * *$ \\
\hline Innovation capability & & .075 & $2.03 * *$ \\
\hline $\mathrm{F}$ & $1.71 * *$ & $.162 * *$ & .045 \\
\hline Adjusted $\mathrm{R}^{2}$ & .137 & $.144 * *$ & $.018^{*}$ \\
\hline$\Delta \mathrm{R}^{2}$ & & \\
\hline
\end{tabular}

$\mathrm{N}=510, * * \mathrm{p}<0.001, * \mathrm{p}<0.01$, standardized coefficients are reported.

Table 9. Mediation test of Innovation capability between Supply Chain Coordination and Enterprise performance

\section{Discussion}

\subsection{The performance mechanism of supply chain coordination}

In this research, the extent to manufacturing capabilities mediates the relationship between supply chain coordination and enterprise performance is examined. This conclusion has made certain theoretical contribution to the performance mechanism of supply chain coordination.

There are two paths in the performance mechanism of supply chain coordination. On the one hand, the supply chain coordination directly improves the enterprise performance, mainly for enhancing the adaptability in enterprise external environment, and obtaining more resources and opportunities; On the other hand, the supply chain coordination indirectly improves the enterprise performance. This study finds that supply chain coordination may renew several manufacturing capabilities. When supply chain coordination influences enterprise performance through the renewal of a specific manufacturing capability, the firm may not improve its performance simply by investing in any random supply chain coordination.

Therefore, it is essential for a firm to understand how its supply chain coordination is linked to its manufacturing capabilities. A lack of such knowledge could prompt firm managers to invest in a dynamic capability that minimally influences firm performance.

\subsection{The dual purpose dynamic capability}

This study has made certain theoretical contribution to the dynamic capability literature. The results show that a firm's supply chain coordination influence five manufacturing capability, but only the quality, cost and flexibility influence performance. Supply chain coordination does not influence performance through neither delivery nor innovation. This perplexing finding can be explained by using the dual purpose dynamic capability concept presented by Helfat and Winter (2011). 
The current dynamic capability framework classifies capabilities as either dynamic or operational, and the framework assumes that these capabilities influence firm performance differently. Operational capabilities directly influence firm performance by helping the firm to maintain its existing operations such as producing outputs using same technology and methods, while dynamic capabilities influence firm performance indirectly by helping the firm renew its existing operations by updating, recombining and reconfiguring its existing operational capabilities. Helfat and Winter (2011) suggest that some capabilities act as both dynamic and operational capabilities and they are used to renew operational capabilities to simultaneously maintain a firm's current operations and to positively influence overall firm performance. They term such capabilities dual-purpose capabilities.

Based on my findings, I posit that supply chain coordination can be viewed as a form of dual-purpose capability. On one hand, supply chain coordination leads to the renewal of the quality, cost and flexibility capability, which in turn positively influences performance. On the other hand, supply chain coordination renews the delivery and innovation capabilities only to maintain a firm's current operations.

In sum, this study contributes to dynamic capability literature by identifying a dual-purpose capability that renews operational capabilities to simultaneously influence performance and to maintain operational capabilities. A firm that understands how a given dynamic capability is linked to its existing operational capabilities will be more successful at renewing its operational capabilities and gaining a competitive advantage than firms that lack such understanding. Therefore, a firm should consider the type of operational capabilities it wishes to renew prior to either developing or deploying its dynamic capabilities. This study also contributes to dynamic capability literature by providing empirical support for the existence of dual-purpose capabilities that can be deployed simultaneously to influence firm performance and maintain a firm's existing operations.

\section{Conclusions}

From the analysis of relationship among supply chain coordination, manufacturing capabilities and enterprise performance, this study proposes that manufacturing capabilities are mediate variables in the performance mechanism of supply chain coordination. We put forward the theoretical model and get the following conclusions by using multiple linear regression analysis:

The results show that the supply chain coordination has a positive relationship on enterprise performance. These results support the hypothesis 1 . The results also show that quality, cost, flexibility fully mediates the relationship between supply chain coordination to enterprise performance. It means that supply chain coordination influences enterprise performance by 
renewing its quality, cost, flexibility capability. Our results also show that while a firm's supply chain coordination is positively related to the delivery and innovation, enterprise performance is not influenced by the renewal of these two manufacturing capabilities. It means that supply chain coordination can help the firm to maintain its operations. This suggests that supply chain coordination may renew several manufacturing capabilities, but may only influence enterprise performance through the renewal of the given manufacturing capabilities. Since a firm's supply chain coordination can simultaneously renew manufacturing capabilities to influence enterprise performance and maintain firm operations, it can be considered a dual-purpose capability.

Like any other study, this paper also has limitations. The data used in study belongs to crosssection data. We failed to study dynamic capabilities' impact on enterprise performance in a temporal dynamic way. These limitations need discussion in future research.

\section{References}

Arshinder, K., Kanda, A., \& Deshmukh, S.G. (2008). Supply chain coordination: perspectives, empirical studies and research directions. International Journal of Production Economics, 115(2), 316-335. http://dx.doi.org/10.1016/j.ijpe.2008.05.011

Ballou, R.H., \& Gilbert, S.M. (2000). New managerial challenges from supply chain opportunities. Industrial Marketing Management, 29(1), 7-18. http://dx.doi.org/10.1016/S00198501(99)00107-8

Brian, F., \& Chris, V.S. (2005). The impact of supply chain relationship dynamics on manufacturing performance. International Journal of Operations \& Production Management, 25(1), 6-19. http://dx.doi.org/10.1108/01443570510572213

Burgess, T.F., Gules, H.K., Gupta, J.N.D., \& Tekin, M. (1998). Competitive priorities, process innovations and time-based competition in the manufacturing sectors of industrializing economies: The case of turkey. Benchmarking for Quality Management \& Technology, 5(4), 304-316. http://dx.doi.org/10.1108/14635779810244478

Clark, T.H., \& Hammond, J.H. (1997). Reengineering channel reordering processes to improve total supply-chain performance. Production and Operations Management, 6(3), 248-265. http://dx.doi.org/10.1111/j.1937-5956.1997.tb00429.x

Corbett, C., \& Van Wassehnove, L. (1993). Trade-offs? what trade-offs? competence and competitiveness in manufacturing strategy. California Management Review, Summer, 107-122. http://dx.doi.org/10.2307/41166757

Danneels, E. (2011). Trying to become a different type of company: Dynamic capability at Smith Corona. Strategic Management Journal, 32(1), 1-31. http://dx.doi.org/10.1002/smj.863 
Eisenhardt, K.M., \& Martin, J.A. (2000). Dynamic capabilities: what are they? Strategic Management Journal, 21(10), 1105-1121.

http://dx.doi.org/10.1002/1097-0266(200010/11)21:10/11<1105: :AID-SMJ133>3.0.CO;2-E

Eng, T.Y. (2005). The influence of a firms cross-functional orientation on supply chain performance. Journal of Supply Chain Management, 41(4), 4-16. http://dx.doi.org/10.1111/j.1745493X.2005.04104002.x

Gan, X., Sethi, S., \& Yan, H. (2004). Supply chain coordination with a risk-averse retailer and a risk-neutra supplier. Productions and Operations Management, 13(2), 135-149. http://dx.doi.org/10.1111/j.1937-5956.2004.tb00150.x

Heimeriks, K.H. (2004). Developing alliance capability. PhD thesis. Einhdoven Universityof Teleology.

Helfat, C.E., \& Peteraf, M.A. (2003). The dynamic resource-based view: Capability lifecycles. Strategic Management Journal, 24(10), 997-1010. http://dx.doi.org/10.1002/smj.332

Helfat, C.E., \& Winter, S.G. (2011). Untangling dynamic and operational capabilities: Strategy for the (n)ever-changing world. Strategic Management Journal, 32(11), 1243-1250. http://dx.doi.org/10.1002/smj.955

Kim, S.W. (2009). An investigation on the direct and indirect effect of supply chain integration on firm performance. International Journal of Production Economics, 119(2), 328-346. http://dx.doi.org/10.1016/j.ijpe.2009.03.007

Koka, B.R., \& Prescott, J.E. (2008). Designing alliance networks: the influence of network position, environmental change and strategy on firm performance. Strategic Management Journal, 29(6), 639-661. http://dx.doi.org/10.1002/smj.679

Li, S.H. (2006). The impact of supply chain management practices on competitive advantage and organizational performance. Omega, 34(2), 107-124.

http://dx.doi.org/10.1016/j.omega.2004.08.002

Morris, M. (2005). Relationship marketing and supplier logistic performance: an extension of the key mediating variables model. Journal of Supply Chain Management, Fall, 32-46. http://dx.doi.org/10.1111/j.1745-493X.2005.04104004.x

Petersen, K.J., Handfield, R.B., \& Ragatz, G.L. (2005). Supplier integration into new product development: coordinating product, process and supply chain design. Journal of Operations Management, 23(3-4), 371-388. http://dx.doi.org/10.1016/j.jom.2004.07.009

Ragatz, G.L., Handfield, R.B., \& Petersen, K.J. (2002). Benefits associated with supplier integration into new product development under conditions of technology uncertainty. Journal of Business Research, 55 (5), 389-400. http://dx.doi.org/10.1016/S0148-2963(00)00158-2 
Reeves, C.A., \& Bednor, D.A. (1994). Defining quality: alternatives and implications. Academy of Management Review, 19(3), 419-45.

Romano, P. (2003). Coordination and integration mechanisms to manage logistics processes across supply networks. Journal of Purchasing \& Supply Management, 9(3), 119-134. http://dx.doi.org/10.1016/S1478-4092(03)00008-6

Rosenzweig, E.D., Roth, A.V., \& Dean, J.W. (2003). The influence of an integration strategy on competitive capabilities and business performance: An exploratory study of consumer products manufacturers. Journal of Operations Management, 21, 437-456. http://dx.doi.org/10.1016/S0272-6963(03)00037-8

Roth, A.V., \& Van Der Velde, M. (1991). Operations as marketing: A competitive service strategy. Journal of Operations Management, 10(3), 303-328. http://dx.doi.org/10.1016/02726963(91)90071-5

Shawnee, K.V. (2003). The effects of an integrative supply chain strategy on customer service and financial performance: An analysis of direct versus indirect relationships. Journal of Operations Management, 21(5), 523-539. http://dx.doi.org/10.1016/j.jom.2003.02.002

Simatupang, T.M., Wright, A.C., \& Sridharan, R. (2002). The knowledge of coordination for supply chain integration. Business Process Management Journal, 8(3), 259-308. http://dx.doi.org/10.1108/14637150210428989

Skinner, W. (1969). Manufacturing - missing link in corporate strategy. Harvard Business Review, May-June, 136-145.

Slater, S.F., \& Narver, J.C. (1994). Does competitive environment moderate the market orientation-performance relationship? Journal of Marketing, 58(1), 46-55.

http://dx.doi.org/10.2307/1252250

Stank, T.P., Crum, M.R., \& Arango, M. (1999). Benefits of inter-firm coordination in food industry in supply chains. Journal of Business Logistics, 20(2), 21-41.

Swink, M., Narasimhan, R., \& Wang, C. (2007). Managing beyond the factory walls: Effects of four types of strategic integration on manufacturing plant performance. Journal of Operations Management, 25, 148-164. http://dx.doi.org/10.1016/j.jom.2006.02.006

Taylor, F.W. (1911). The principles of scientific management. New York, London: Harper \& Brothers.

Teece, D.J. (2007). Explicating dynamic capabilities: The nature and microfoundations of (sustainable) enterprise performance. Strategic Management Journal, 28(13), 1319-1350. http://dx.doi.org/10.1002/smj.640 
Teece, D.J., Pisano, G., \& Shuen, A. (1997). Dynamic capabilities and strategic management. Strategic Management Journal, 18(7), 509-533.

http://dx.doi.org/10.1002/(SICI)1097-0266(199708)18:7<509::AID-SMJ882>3.0.CO;2-Z

Vickery, S.K., Jayaram, J., Droge, C., \& Calantone, R. (2003). The effects of an integrative supply chain strategy on customer service and financial performance: An analysis of direct versus indirect relationships. Journal of Operations Management, 21(5), 523-539. http://dx.doi.org/10.1016/j.jom.2003.02.002

Wang, C.L., \& Ahmed, P.K. (2007). Dynamic capabilities: A review and research agenda. International Journal of Management Reviews, 9(1), 31-51. http://dx.doi.org/10.1111/j.14682370.2007.00201.x

Wang, Y.P., \& Meng, W.D. (2004). Evolutionary game analysis on co-competition mechanism of supply chain. Journal of Industrial Engineering and Engineering Management, 18(2), 96-98.

Ward, P.T., Duray, R., Leozzg, G.K., \& Sum, C. (1995). Business environment, operations strategy and performance: An empirical study of Singapore manufacturers. Journal of Operations Management, 13, 99-115. http://dx.doi.org/10.1016/0272-6963(95)00021-J

Wong, C.Y., Sakun, B., \& Wong, C.W.Y. (2011). The contingency effects of environmental uncertainty on the relationship between supply chain integration and operational performance. Journal of Operations Management, 29(6), 604-615.

http://dx.doi.org/10.1016/j.jom.2011.01.003

Zott, C. (2003). Dynamic capabilities and the emergence of intra industry differential firm performance: Insights from a simulation study. Strategic Management Journal, 24(2), 97-125. http://dx.doi.org/10.1002/smj.288

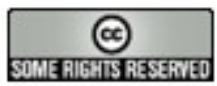

Article's contents are provided on a Attribution-Non Commercial 3.0 Creative commons license. Readers are allowed to copy, distribute and communicate article's contents, provided the author's and Journal of Industrial Engineering and Management's names are included. It must not be used for commercial purposes. To see the complete license contents, please visit http://creativecommons.org/licenses/by-nc/3.0/. 